\title{
Evaluation of Spent Engine Oil and Other Natural Materials on the Emergence of Harvester Ants (Messor galla Forel)
}

\author{
Emmanuel Okrikata1,*, Chinwe Edith Anaso², Sani Mai Bukar ${ }^{3}$ \\ ${ }^{1}$ Federal University Wukari, Taraba State, Nigeria \\ 2University of Maiduguri, Borno State, Nigeria \\ ${ }^{3}$ Federal College of Education (Technical), Potiskum, Yobe State, Nigeria \\ *Corresponding Author E-mail: eokrikata@gmail.com
}

Received: 13 March 2019, Revised: 30 May 2019, Accepted: 1 June 2019

\begin{abstract}
Harvester ants (Messor galla Forel) would defy various control strategies. Two field experiments were conducted to evaluate the effects of spent engine-oil and other naturebased materials on their emergence in Maiduguri, Borno State of Nigeria. The evaluated treatments are spot applications of spent engine-oil and some natural materials in experiment 1 and individual and equal mixture of pure neem seed kernel oil and spent engine-oil in experiment 2. Spot application of permethrin served as positive control. Experiment 1 results showed no significant difference $(p>0.05)$ between permethrin and spent engine-oil (which was the most effective treatment). While neem seed oil was significantly $(\mathrm{p}<0.01)$ more effective than the untreated control, the result on the $28^{\text {th }}$ day after application showed no significant difference $(p>0.05)$ in the population index of ants that emerged from nests treated with aqueous neem seed extract, salt/potash solution and extract of Eugenia aromatica fruit from those of the untreated control. Experiment 2 result showed no significant difference $(\mathrm{p}<0.05)$ between Permethrin, spent engine-oil, neem seed kernel oil and an equal mixture by volume of pure neem seed kernel oil and spent engineoil in suppressing the emergence of the ants. These were, however, significantly different ( $p>0.05)$ from the untreated control. While the result shows no significant difference between the insecticidal treatments, it was observed that equal mixture of spent engine-oil and neem seed kernel oil was the most effective, followed by spent engine-oil, permethrin and neem seed kernel oil in that order.
\end{abstract}

Key words: Harvester ants (Messor galla F.), Permethrin, Spent engine-oil, Neem seed oil.

\section{Introduction}

Harvester ants, Messor galla Forel, have been established to be a serious granivorous field and store insect pest of small grain cereals in the tropics and sub-tropics (Degri et al., 2013; Briggs et al., 2016). They form complex colonies and are soil dwelling as their foraging activity may interfere with sowing and harvesting of grains. Cereal grains like 
Millet, Wheat, Sorghum and Rice are major staple foods and raw materials in bakeries and brewing industries which have been reported to be ravaged by the activities of harvester ants (Nicola et al., 2013). As a field and store pest, the harvester ant causes extensive damage and losses by foraging on sown seeds, sometimes feeding on germinated crops and also climbing some plants to harvest matured seeds/grains (Heathwole, 1996; Tschinkel and Kwapich, 2016).

They also reduce plant stands by denudation of cultivated lands as they destroy the plants around the entrance to their nest leading to bare patches in the fields measuring several square metres. Hence, large areas for crop production have been lost year after year by the activities of harvester ants (Nicola et al., 2013). The need to search for a cheaper and environmentally amenable pest management strategy that can be incorporated into the Integrated Pest Management (IPM) of harvester ants has become apparent in view of its importance as yield reducer and the significance of cereal grains most especially in the semi arid Northern Nigeria.

The fact that a good number of small cereal grains, like Millet, are mostly cultivated at subsistence level in the savanna regions of Nigeria (Marsh, 1987), points to the need to device or recruit a cheaper means of control. In Borno State of Nigeria as in some other places, Pif-Paf (Permethrin) is a most common insecticide used in controlling this insect pest. Aside cost, there is a wide cry for reduction in the quantity of chemical pesticides used due to the associated risks. It has also been reported that farmers in France added spent engine oil to synthetic insecticides for greater effect (Chandrasiri and Fernando, 2004). This implies that spent engine oil could be a synergist by making the insecticide more insecticidal.

Spent engine oil have also been applied into the poles of granaries to repel termites. Resource limited farmers have also been reported to use spent engine oil to control external parasites (mites, fleas, lice and tick) on free-range chickens at Amatola basin, in eastern cape of South Africa (Heathwole, 1996; Chandrasiri and Fernando, 2004; Briggs et al., 2016). Spent engine oil has also been shown to contain Polycyclic aromatic hydrocarbons which cause adverse effects on man, plants, microbes and aquatic lives (Adenipekun et al., 2008; Abdul-Shafy et al., 2016). However, they are biodegradable in the soil within certain limits as soils have inherent abilities to remediate contaminants unlike some recalcitrant pesticides (Abioye et al., 2012). They are easily accessible at mechanic workshops in most urban centres in Africa.

Several reports have shown that Neem seed kernel oil is efficacious in pest management and non persistent, hence environmentally friendly. This research is therefore aimed at assessing the efficacy of spent engine oil and other natural materials in suppressing harvester ants.

\section{Materials and methods}

\section{Choice of test sites}

Areas infested with harvester ants nest were located within Maiduguri, Borno State of Nigeria. The surroundings of the nests, about one meter radius from the nest hole, were cleared of grasses and debris. The presence of the ants in the sampled nests was ascertained by placing untreated millet grains some $50 \mathrm{~cm}$ from the harveter ants' nest 
entrance. The population of the ants was then recorded using the rating scale (population index) shown below.

\section{Experimental Design}

Two experiments were conducted using a Randomized Complete Block Design (RCBD) with seven (7) treatments in experiment 1 and five (5) treatments in experiment 2 both in four (4) replicates. Therefore a total of forty-eight (48) nests were used for the experiments.

\section{Treatments evaluated}

The treatments evaluated for experiment 1 were;

1. Pif-paf powder (permethrin)

2.Aqueous neem seed extract

3. Neem seed oil

4. Spent engine oil

5. Salt and potash solution

6. Extract of Eugenia aromatica Kunt. fruit

The treatments evaluated for experiment 2 were;

1. Permethrin

2. Neem Seed Kernel Oil (NSKO)

3. Spent Engine Oil

4. Equal mixture by volume of; Neem Seed Kernel Oil + Spent Engine Oil (NSKO + UEO)

For both experiments, nests with no material applied served as control.

\section{Procedure for preparation and application of treatments}

1.Pif-paf (Permethrin): 125 g of pif-paf powder was turned into 5 litres of water (i.e., 25 $\mathrm{g} / \mathrm{l}$ ), thoroughly shaken and was poured (2 litres) into separate harvester ant nests through the entrance/opening of the nests.

2. Aqueous neem seed extract: $250 \mathrm{~g}$ of ground neem kernel was turned into 5 litres of water (i.e., $50 \mathrm{~g} / \mathrm{l}$ ), shaken very well and left to stand for 12 hours. The mixture was then sieved and poured ( 2 litres) into separate harvester ant nests.

3. Neem seed oil: Neem seed oil was procured and poured (2 litres) in separate harvester ant nest.

4. Spent engine oil: Spent engine oil was obtained from mechanic workshops and poured (2 litres) into separate harvester ants nests.

5. Salt and potash solution: $125 \mathrm{~g}$ of salt and ground potash was turned in 5 litres of water, thoroughly shaken and left to stand for 12 hours. It was then sieved and poured (2 litres) into separate harvester ant nests.

6. Extract of Eugenia aromatica fruit: $250 \mathrm{~g}$ of the fruit was turned in 5 litres of water, shaken very well and left to stand for 12 hours. It was then sieved and poured (2 litres) into separate harvester ant nests.

7. Equal volume of Neem Seed Kernel Oil + Spent Engine Oil was poured (2 litres) in to separate harvester ants nests. 
After three (3) hours of treatment application to allow for stabilization of the nests, untreated millet seeds were again placed $30 \mathrm{~cm}$ away from the nest entrance. This was done to boost ant's foraging activity.

\section{Data collection}

Data on harvester ants' population were taken using the population index describe below, a day after application and subsequently at weekly interval for four (4) weeks at about 2000 hours (8 pm).

The population index used was;

$1=<10$ ants

$2=11-30$ ants

$3=31-50$ ants

$4=51-70$ ants

$5=71-90$ ants

$6=91-110$ ants

$7=>110$ ants

\section{Data analysis}

The collected data were subjected to analyze variance (ANOVA) using the analytical software, 1989, statistix version 3.1 (SX) and significant difference between treatments was separated using the Duncan Multiple Range Test at 5\% level of probability.

\section{Results}

\section{Experiment 1}

Table 1 shows that there was no significant difference $(p>0.05)$ between the treatments in terms of the population index of the harvester ants before the treatments were applied. However, on the $1^{\text {st }}$ day post treatment application, all the other treatments, aside salt/potash solution, had lower population $(\mathrm{p}<0.05)$ of emerging harvester ants as compared to that of the control nests with permethrin and spent engine oil having the higher suppressive effect. On the $7^{\text {th }}$ day after application, ant density on aqueous neem seed extract and salt/potash solution treated nests were statistically at par with those on control. The Table further shows that, on the fourteenth day post treatment, ants density in nests treated with aqueous neem seed extract, salt/potash solution and the extract of Eugenia aromatica fruit were not significantly ( $p>0.05)$ different from those on the control. Although neem seed oil was significantly $(p<0.05)$ more effective than the treatments aforementioned, it was significantly less effective than permethrin and spent engine oil. A similar trend was observed on the $21^{\text {st }}$ and $28^{\text {th }}$ day post application.

\section{Experiment 2}

The results as shown in Table 2 indicate no significant difference $(p<0.05)$ between Permethrin, spent engine oil, neem seed kernel oil and, equal mixture by volume of pure neem seed kernel oil and spent engine oil in controlling the emergence of the ants. These were however, significantly different $(p>0.05)$ from the untreated control. 
While the result shows no significant difference among the insecticidal treatments, it was observed that equal mixture of spent engine oil and neem seed kernel oil was most effective, followed by spent engine oil, Permethrin and neem seed kernel oil, in that order.

Table 1. Effect of nature-based materials on the population index of harvester ants (Messor galla Forel)

\begin{tabular}{ccccccc}
\hline Treatment & BA & 1 DAA & 1 WAA & 2 WAA & 3 WAA & 4 WAA \\
\hline Untreated control & $6.00^{\mathrm{a}}$ & $6.00^{\mathrm{a}}$ & $6.00^{\mathrm{a}}$ & $6.00^{\mathrm{a}}$ & $6.00^{\mathrm{a}}$ & $6.00^{\mathrm{a}}$ \\
Permethrin & $6.00^{\mathrm{a}}$ & $1.00^{\mathrm{c}}$ & $1.00^{\mathrm{d}}$ & $1.00^{\mathrm{c}}$ & $1.00^{\mathrm{c}}$ & $1.00^{\mathrm{c}}$ \\
Aqueous neem seed & & & & & & \\
extract & $6.00^{\mathrm{a}}$ & $4.75^{\mathrm{b}}$ & $5.50^{\mathrm{ab}}$ & $6.00^{\mathrm{a}}$ & $6.00^{\mathrm{a}}$ & $6.00^{\mathrm{a}}$ \\
Neem seed oil & $6.00^{\mathrm{a}}$ & $1.75^{\mathrm{c}}$ & $2.25^{\mathrm{c}}$ & $2.25^{\mathrm{b}}$ & $2.25^{\mathrm{b}}$ & $2.25^{\mathrm{b}}$ \\
Spent engine oil & $6.00^{\mathrm{a}}$ & $1.00^{\mathrm{c}}$ & $1.00^{\mathrm{d}}$ & $1.00^{\mathrm{c}}$ & $1.00^{\mathrm{c}}$ & $1.00^{\mathrm{c}}$ \\
Salt/potash solution & $6.00^{\mathrm{a}}$ & $6.00^{\mathrm{a}}$ & $6.00^{\mathrm{a}}$ & $6.00^{\mathrm{a}}$ & $6.00^{\mathrm{a}}$ & $6.00^{\mathrm{a}}$ \\
Extract of E. aromatica & $6.00^{\mathrm{a}}$ & $5.00^{\mathrm{ab}}$ & $5.25^{\mathrm{b}}$ & $5.50^{\mathrm{a}}$ & $6.00^{\mathrm{a}}$ & $6.00^{\mathrm{a}}$ \\
SE \pm & 0.00 & 0.29 & 0.18 & 0.14 & 0.09 & 0.09 \\
\hline
\end{tabular}

1. NSKO = Neem seed kernel oil

2. SEO = Spent engine oil

3. $\mathrm{BA}=$ Before application

4. WAA = Weeks after application

Values with identical superscript alphabets do not differ significantly at $p<0.05$

Table 2. Discrete and interactive effects of neem seed kernel oil and spent engine oil on the population index of harvester ants (Messor galla Forel)

\begin{tabular}{ccccccc}
\hline Treatment & BA & 1 DAA & 1 WAA & 2 WAA & 3 WAA & 4 WAA \\
\hline NSKO & $6.00^{\mathrm{a}}$ & $1.25^{\mathrm{b}}$ & $1.25^{\mathrm{b}}$ & $1.25^{\mathrm{b}}$ & $1.5^{\mathrm{b}}$ & $1.5^{\mathrm{b}}$ \\
SEO & $6.00^{\mathrm{a}}$ & $1.00^{\mathrm{b}}$ & $1.00^{\mathrm{b}}$ & $1.00^{\mathrm{b}}$ & $1.00^{\mathrm{b}}$ & $1.00^{\mathrm{b}}$ \\
& & & & & & \\
NSKO + SEO & $6.00^{\mathrm{a}}$ & $1.00^{\mathrm{b}}$ & $1.00^{\mathrm{b}}$ & $1.00^{\mathrm{b}}$ & $1.00^{\mathrm{b}}$ & $1.00^{\mathrm{b}}$ \\
& & & & & & \\
Permethrin & $6.00^{\mathrm{a}}$ & $1.00^{\mathrm{b}}$ & $1.00^{\mathrm{b}}$ & $1.00^{\mathrm{b}}$ & $1.00^{\mathrm{b}}$ & $1.00^{\mathrm{b}}$ \\
& & & & & & \\
Untreated & & & & & & \\
Control & $6.00^{\mathrm{a}}$ & $6.00^{\mathrm{a}}$ & $6.00^{\mathrm{a}}$ & $6.00^{\mathrm{a}}$ & $6.00^{\mathrm{a}}$ & $6.00^{\mathrm{a}}$ \\
SE \pm & 0.00 & 0.22 & 0.22 & 0.22 & 0.39 & 0.39 \\
\hline
\end{tabular}

Values with identical superscript alphabets do not differ significantly at $p<0.05$

\section{Discussion}

Harvester ants (Messor galla Forel) are voracious granivorous species which have negative impact on crop production on field and in store. They are also threats to non-farmers as they destroy structures by digging their nests on or near the structures and their presence encourages soil erosion (Helmy et al., 2012). There is hardly any viable alternative to synthetic insecticides for their control in the semi-arid regions of Nigeria as the cost of which is a limitation for both the 
resource limited farmers and non-farmers alike. This is aside the environmental and health implication of synthetic pesticides.

Aside spent engine oil being the most efficacious; it was able to synergize the efficacy of neem seed kernel oil which has been reported widely to be an environmentally friendly pest management tool. This is also in line with the report that farmers in France use Spent Engine oil to synergize synthetic insecticides (Chandrasiri and Fernando, 2004). Permethrin is a strong systemic insecticide with contact, stomach and repellent effect. These characteristics may also be attributed to spent engine oil and neem seed kernel oil as it has been shown that mineral oil based insecticides exhibit the following modes of action against insects: blocking their spiracles and causing asphyxiation, creating thin layer on insects' eggs surface thereby preventing gas exchange, acting as poison by interacting with their fatty acids and interfering with their normal metabolism, causing death of newly hatched individuals and causing hardness in eggs which makes them difficult to hatch (Helmy et al., 2012).

This research finding shows that, spent engine oil may be used in circumstances where the rate of infestation is low. Since it involves spot application, any likely negative environmental impact will be less. Where there is moderate level of infestation, the mixture of equal volume of neem and spent engine oil may be used to further lower the quantity of spent engine oil to be used. However, where the infestation level is high, pure neem seed oil can be used since it is not persistent and is environmentally friendly.

\section{Conclusion}

The performance of permethrin and spent engine oil in these experiments suggests that they have knockdown and repellent effects on the harvester ant species. The use of the oil formulations would be able to save hard currency spent in importing pesticides and, the wasteful and indiscriminate discharge of spent engine oil would be better channeled to a more productive use by way of controlling harvester ants. This study have brought to the fore, probably for the first time, the potential of spent engine oil and neem kernel oil individually or compositely as a cheaper, technically effective and conservation minded alternative to synthetic pesticide in harvester ant management.

\section{References}

Abdul-Shafy, HI, Mansour, MSM. (2016). A review of polycyclic aromatic hydrocarbons: Source, environmental impact, effect on human health and remediation. Egypt. J. of Petrol., 25(1): 107-123.

Abioye, OP, Agamuthu, P, Abdul Aziz, AR. (2012). Biodegradation of used motor oil in soil using organic waste amendments. Biotech. Res. Intl., Article ID 587041, 8 pages, http://dx.doi.org/10.155/2012/587041

Adenipekun, CO, Oyetungi, OJ, Kassim, LS. (2008). Effects of spent engine oil on the growth parameters and chlorophyll content of Corchorus olitonus. Environmentalist, 28(1):446 - 450.

Briggs, CM, Redak, RA. (2016) Seed Selection by the Harvester Ant Pogonomyrmex rugosus (Hymenoptera: Formicidae) in Coastal Sage Scrub: Interactions with Invasive Plant Species. Environ Entomol., 45(4): 983 - 90. 
Chandrasiri, KAS, Fernando, LCP. (2004) Effectiveness of Used Engine Oil in the Management of Coconut Mite, Aceria guerreronis (Acari: Eriophyidae). Cocos. 16: 43-55.

Degri, MM, Sharah, HA, Maina, YT, Musa, HS. (2013). The effect of harvester ants (Messor spp) nests on farmers' productivity in semi-arid zone of Maiduguri, Nigeria. J. Environ. Issue. Agric. Develop. Countries, 5(1):34-39.

Heathwole, H. (1996). Ant assemblages at their dry limits, the northern Alacama Deserts, Pere and the Chott EL-Djerid. Tunis. J. Arid. Environ., 33:449-456.

Helmy, EI, Kwaiz, FA, El-Sahn, OMN. (2012). The usage of mineral oils to control insects. Egypt. Acad. J. Biolog. Sci., 5(3):167-174.

Marsh, AC. (1987). The foraging ecology of two Namib desert harvester ant species. South Afric J. of Zool., 22(2): 130-36.

Nicola, JRP, Robert, AJ, Bert, H. (2013). Foraging behavior in the ant genus Messor (Hymenoptera: Formicidae: Myrmicinae). Myrmecological News. 18: 33-49.

Tschinkel, WR, Kwapich, CL. (2016). The Florida harvester ants, Pogonomyrmex badius, relies on germination to consume large seeds. PlosOne, 11(11): e0166907. doi:10.1371/journal.pone.0166907.

How to cite this article: Emmanuel Okrikata, Chinwe Edith Anaso, Sani Mai Bukar. Evaluation of Spent Engine Oil and other Natural Materials on the Emergence of Harvester Ants (Messor galla Forel). International Journal of Advanced Biological and Biomedical Research, 2019, 7(4), 335-341. Link: http://www.ijabbr.com/article 35441.html 